\title{
Effect of Effluent Recirculation on Biogas Production Using Two-Stage Anaerobic Digestion of Citrus Waste
}

\author{
Lukitawesa ${ }^{1, *\left(\mathbb{D}, \text { Rachma Wikandari }^{2}, \text { Ria Millati }^{2} \text {, Mohammad J. Taherzadeh }\right.}{ }^{1}(\mathbb{D}$ and \\ Claes Niklasson ${ }^{3}$ \\ 1 Swedish Center for Resource Recovery, University of Borås, 50190 Borås, Sweden; \\ Mohammad.taherzadeh@hb.se \\ 2 Department of Food and Agricultural Product Technology, Universitas Gadjah Mada, Yogyakarta 55281, \\ Indonesia; rachma_wikandari@mail.ugm.ac.id (R.W.); ria_millati@ugm.ac.id (R.M.) \\ 3 Department of Chemical Reaction Engineering, Chalmers University of Technology, 41296 Göteborg, \\ Sweden; claesn@chalmers.se \\ * Correspondence: lukitawesa.lukitawesa@hb.se; Tel.: +46-33-4354612
}

Received: 4 October 2018; Accepted: 16 December 2018; Published: 19 December 2018

\begin{abstract}
Citrus waste is a promising potential feedstock for anaerobic digestion, yet the presence of inhibitors such as D-limonene is known to limit the process. Effluent recirculation has been proven to increase methane yield in a semi-continuous process for recalcitrant material, but it has never been applied to toxic materials. This study was aimed to investigate the effect of recirculation on biogas production from citrus waste as toxic feedstock in two-stage anaerobic digestion. The first digestion was carried out in a stirred tank reactor (STR). The effluent from the first-stage was filtered using a rotary drum filter to separate the solid and the liquid phase. The solid phase, rich in hydrophobic D-limonene, was discarded, and the liquid phase containing less D-limonene was fed into the second digester in an up-flow anaerobic sludge bed (UASB) reactor. A high organic loading rate (OLR $5 \mathrm{~g} \mathrm{VS} /(\mathrm{L} \cdot$ day)) of citrus waste was fed into the first-stage reactor every day. The effluent of the first-stage was then fed into the second-stage reactor. This experiment was run for 120 days. A reactor configuration without recirculation was used as control. The result shows that the reactor with effluent recirculation produced a higher methane yield (160-203 NmL/g.VS) compared to that without recirculation (66-113 NmL/g.VS). More stable performance was also observed in the reactor with recirculation as shown by the $\mathrm{pH}$ of $5-6$, while without recirculation the $\mathrm{pH}$ dropped to the range of 3.7-4.7. The VS reduction for the reactor with recirculation was 33-35\% higher than that of the control without recirculation. Recirculation might affect the hydrolysis-acidogenesis process by regulating $\mathrm{pH}$ in the first-stage and removing most of the D-limonene content from the substrate through filtration.
\end{abstract}

Keywords: biogas; anaerobic digestion; citrus waste; recirculation; STR; UASB

\section{Introduction}

Citrus fruits are among the most consumed types of fruit globally due to their massive productivity, low price, and healthy dietary properties [1,2]. Its production throughout the world increased by $20.6 \%$ from 2006 to 2016, to 132.4 million tones [3]. Citrus fruits are commonly used for juice production, in which $50 \%$ in weight of citrus fruits end up as solid waste during the extraction process [1,2]. The citrus waste has high water (80-90\%) and organic matter (95\%) content [4]. These properties make citrus waste a potential substrate for anaerobic digestion. However, the low $\mathrm{pH}(3-4)$ and the presence of citrus essential oil pose obstacles for this use. 
The major component of citrus essential oil (CEO) in citrus waste is D-limonene, which makes up $68-98 \%$ of sweet orange essential oil [5]. Several studies have shown the inhibition effect of D-limonene on anaerobic digestion of citrus waste. Mizuki et al. [6] reported that the limit dosage of D-limonene was $26 \mathrm{mg} /(\mathrm{L} \cdot$ day). Wikandari et al. [7] reported that the methane production of single-stage anaerobic digestion halted at an organic loading rate (OLR) of $1.5 \mathrm{~g}$ VS/(L·day). Their study showed that VFA (volatile fatty acids) started to be accumulated around $7.5 \mathrm{~g} / \mathrm{L}$, which indicated that the inhibition occurred in the system at this OLR.

Co-digestion has been studied as a strategy for overcoming the inhibition effect caused by D-limonene [8]. However, the results were not as expected. Co-digestion of citrus waste with cow dung at a ratio of 1:1 resulted in low methane yield [9]. Forgacs et al. [10] previously reported that co-digestion of citrus waste and the organic fraction of municipal solid waste with a percent ratio of 30:70 was successfully conducted up to an OLR of $3 \mathrm{~g} \mathrm{VS} /(\mathrm{L} \cdot$ day). However, the system failed at higher OLRs. Similarly, Martín et al. [11] reported that anaerobic co-digestion of orange peel with glycerol (1:1) resulted in stable operation up to an OLR of $1.91 \mathrm{~g} \mathrm{VS/(L \cdot day),} \mathrm{but} \mathrm{failed} \mathrm{at} \mathrm{higher}$ OLRs. These studies imply that co-digestion of citrus waste is not suitable for operation at high OLRs. In addition, co-digestion can only treat a relatively low amount of citrus waste, which makes it undesirable from an industrial point of view. Hence, an alternative solution is needed.

Two-stage digestion with recirculation is a potential approach to address the inhibition problem. In two-stage digestion, the acid and methane forming processes are separated. Acid forming (hydrolytic, acidogenic, and acetogenic microorganisms) and methane forming (methanogens) microorganisms have different $\mathrm{pH}$ requirements for their optimum growth. Methanogens are considered as the microorganisms more sensitive to inhibitors (in this case D-limonene) and low $\mathrm{pH}$. Therefore, the separation of the acid forming from the methane forming process could protect methanogens from an acidic environment. The first-stage has an optimum $\mathrm{pH}$ for acidophilic microorganisms 5.0-6.5 [12], whereas the optimum $\mathrm{pH}$ for hydrogen production is 5.5-6 [13]. The second-stage, which is dedicated to methane production, has an optimum $\mathrm{pH}$ of 7-8 [14]. The accumulation of VFA produced during acidogenesis in the first-stage generally decreases the $\mathrm{pH}$ below the optimal value [15].

Another way to protect the methanogens from D-Limonene could be to filtrate the effluent from the acid forming process in the first-stage prior to feeding it into the methane forming process in the second-stage. The D-limonene released from the peel during hydrolysis has low solubility in water [16], and therefore mostly stays with the undigested solid residue.

Anaerobic digestion of citrus waste at high OLRs resulted in a $\mathrm{pH}$ drop in the first-stage reactor, which is not favorable for the growth of acid-forming bacteria. In order to maintain the $\mathrm{pH}$, a base can be added to the first-stage reactor. This approach, however, is costly and less environmentally friendly. Gottardo et al. [17] reported that effluent from the second-stage digester is rich in buffering agents. Hence recirculation of the effluent from the reactor of the second-stage might help to maintain the $\mathrm{pH}$ in the reactor of the first-stage. Recirculation of effluent from the second-stage into the first-stage in anaerobic digestion of starch and cotton resulted in higher degradability (91\% and 80\%, respectively) compared to without recirculation (82\% and 56\%) [18]. Therefore, the aim of this work was to investigate the efficacy of combining two-stage digestion, filtration, and recirculation for mitigating the inhibition effect of the natural low $\mathrm{pH}$ and $\mathrm{D}$-limonene content of citrus waste in anaerobic digestion.

\section{Materials and Methods}

\subsection{Inoculum}

The STR (stirred tank reactor) used in the first-stage was inoculated with sludge obtained from the $3000 \mathrm{~m}^{3}$ thermophilic biogas plant $\left(55^{\circ} \mathrm{C}\right)$ at Borås Energy and Environment $\mathrm{AB}$ (Borås, Sweden). The sludge was stored in an incubator at a temperature of $55^{\circ} \mathrm{C}$ for $2-3$ days. The sludge was shaken in order to obtain homogenous inoculum. Any remaining large particles were separated by passing the sludge through a sieve with a pore size of $1 \mathrm{~mm}$. An up-flow anaerobic sludge blanket (UASB) 
reactor used in the second-stage digestion was inoculated with granulated anaerobic sludge, which was obtained from a pilot scale UASB reactor treating municipal wastewater at Hammarby Sjöstad (Stockholm, Sweden).

\subsection{Citrus Waste}

The citrus waste used in this work was orange residue obtained from juice processing at the Brämhult factory (Borås, Sweden) and stored at $-20^{\circ} \mathrm{C}$ prior to use. The citrus waste was thawed and homogenized to obtain the citrus waste slurry. The characteristic of citrus waste used in this experiment are shown in Table 1. The D-limonene content of the citrus waste was analyzed using gas chromatography-mass spectrometry (GC-MS, Trace GC Ultra, ThemoScientific, Waltham, MA, USA).

Table 1. Characteristics of the citrus waste used in this experiment [19].

\begin{tabular}{lc}
\hline \multicolumn{1}{c}{ Components } & Content $(\mathbf{\%} \mathbf{d b} *)$ \\
\hline Total Solid (TS) & 23.99 \\
Volatile Solid (VS) & 23.07 \\
Water & 79.07 \\
Ash & 0.88 \\
Fat & 0.23 \\
Total Protein & 1.28 \\
Crude Fiber & 3.28 \\
Carbohydrate & 18.54 \\
Starch & 0.62 \\
\hline
\end{tabular}

\subsection{Reactors}

The reactor used in the first-stage was an STR (Bioprocess Control AB, Lund, Sweden) with a volume of $2 \mathrm{~L}$ and a working volume of $1.5 \mathrm{~L}$. The reactor used in the second-stage was a UASB (Scotch Duran, Mainz, Germany) with a volume $0.5 \mathrm{~L}$ and a working volume of $0.4 \mathrm{~L}$. The temperature of the first-stage reactor was maintained at $55^{\circ} \mathrm{C}$, while the second-stage reactor was maintained at $37^{\circ} \mathrm{C}$. Both reactors were equipped with a feeding inlet, a liquid sampling point, an effluent outlet, and a gas line to the gas measuring system which was equipped with a gas sampling port.

\subsection{Experimental Procedure}

The STR was seeded with thermophilic anaerobic digestion sludge from biogas plant as mentioned in Section 2.1. The UASB reactor was seeded with granulated anaerobic sludge as mentioned in Section 2.1. The first-stage reactor was fed with citrus waste at OLR of $0.5 \mathrm{~g} \mathrm{VS/(L \cdot day)} \mathrm{and} \mathrm{then}$ increased stepwise every 1 week until reaching OLR $5 \mathrm{~g}$ VS/(L·day). The two-stage digestion with (Figure 1A) and without (Figure 1B) effluent recirculation. The first-stage of the systems were STR bioreactors with $2 \mathrm{~L}$ volume while the second-stage was a up-flow anaerobic sludge blanket (UASB) bioreactor with $0.4 \mathrm{~L}$ volume containing flocculated microorganism. The slurry outlet of the first-stage passed a rotary drum filter (Steadfast Equipment, Howell, NJ, USA) containing a polyamide cartridge with pore size of $70 \mu \mathrm{m}$ to separate liquid from remaining solid particles. The solid particles (retentate) was discharged from filter, while the liquid part was fed into the UASB (second-stage) bioreactors. Both systems were fed with citrus wastes. The differences between the two systems was whether the effluent of the second-stage was fed back to the first stage bioreactor or not (conferatur Figure 1). 

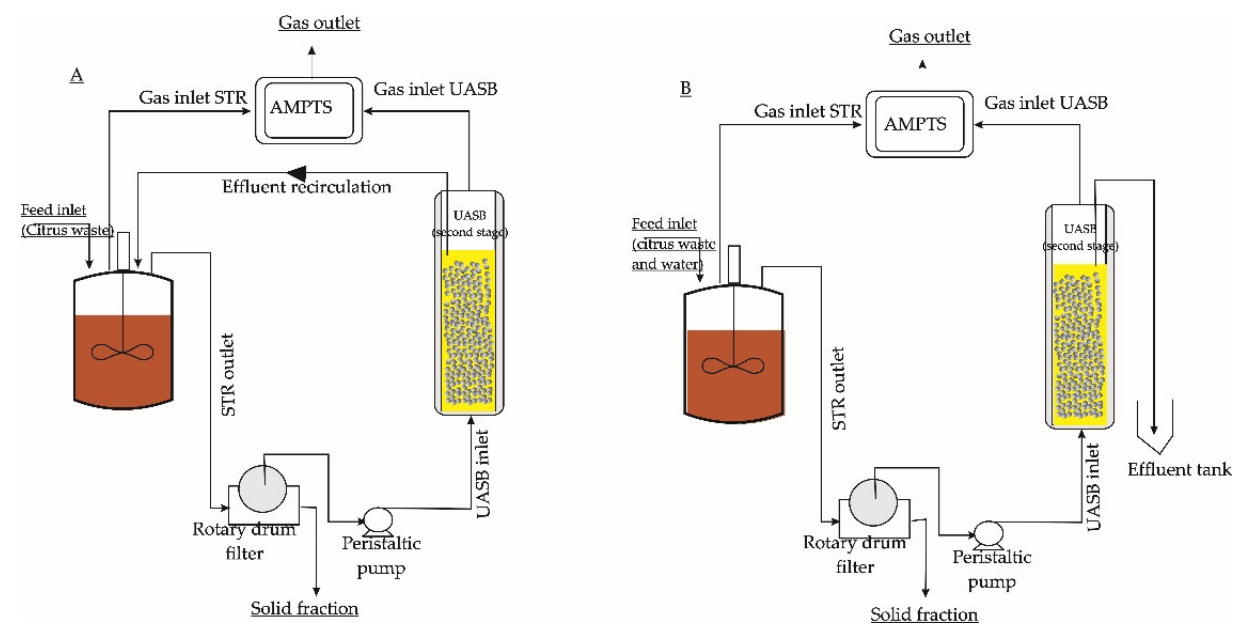

Figure 1. Schematic figure of the semi-continuous two-stage system with liquid recirculation (A) and without recirculation (B) (modified from Aslanzadeh et al. [20]). AMPTS = Automatic Methane Potential Testing System; STR = Stirred tank Reactor; UASB = up-flow anaerobic sludge blanket.

For the system with effluent recycling (Figure 1A), the hydraulic retention time (HRT) in the first-stage reactor was 15 days. Prior to feeding, the citrus waste was diluted with effluent from second-stage reactor until the volume reached $100 \mathrm{~mL}$. At the beginning of the experiment (day 0), the OLR was started at $1 \mathrm{~g} \mathrm{VS/(L \cdot day)} \mathrm{and} \mathrm{then} \mathrm{increased} \mathrm{step} \mathrm{wise} \mathrm{into} \mathrm{OLR} \mathrm{of} 5 \mathrm{~g} \mathrm{VS/(L \cdot day)} \mathrm{during} \mathrm{day}$ 0 until day 47 . The digestate from first-stage was filtered using rotary drum filter. In the second-stage reactor, the HRT was set at 3 days to adapt the microorganisms. Afterwards, it was shortened step wise into 1.5 days by increasing the volume of the feeding. The whole experiment was carried out in 120 days. The two-stage digestion without recirculation (Figure 1B) was carried out as the same procedure including the HRT, OLR, and filtration. The difference was the liquid that used for diluting the citrus waste was water (not the effluent from second-stage). The liquid from the second-stage was discharged from the system. The whole experiment was carried out in 120 days.

The volume of biogas production was recorded continuously by an Automatic Methane Potential Testing System (AMPTS, Bioprocess Control AB, Lund, Sweden). The biogas composition was analyzed using gas chromatography. The liquid and gas sampling were performed 3-4 times a week. The liquid samples were kept at $-20^{\circ} \mathrm{C}$ until the analyses were performed.

\subsection{Analytical Method}

\subsubsection{Analysis of Gas Fraction}

The composition of biogas production was measured using a gas chromatograph (Auto System Perkin-Elmer, Waltham, MA, USA), equipped with a packed column (Perkin Elmer, $6^{\prime} \times 1.8^{\prime \prime}$ OD, $80 / 100$ Mesh) and a thermal conductivity detector (Perkin Elmer). The injector temperature was $150{ }^{\circ} \mathrm{C}$, detection temperature was $200{ }^{\circ} \mathrm{C}$, and oven temperature was $75^{\circ} \mathrm{C}$. The carrier gas was pure nitrogen at a pressure of $0.70 \mathrm{bar}$ and a flow rate of $40 \mathrm{~mL} / \mathrm{min}$ at $60^{\circ} \mathrm{C}$. A $250 \mu \mathrm{L}$ pressure-tight gas syringe (VICI, Precision Sampling Inc., Baton Rouge, LA, USA) was used for the gas sampling.

\subsubsection{Analysis of Liquid Fraction}

Liquid samples were analysed for $\mathrm{pH}$, soluble COD, and VFA concentration after centrifugation at $17,000 \times g$ for $10 \mathrm{~min}$ and subsequent filtration through a $0.2-\mu \mathrm{m}$ filter to remove solid particles. Glucose and fructose content of substrate were determined with Sucrose/D-Fructose/D-Glucose assay kit (Megazyme, Chicago, IL, USA). The COD was measured using a HACH apparatus equipped with a UV-Vis spectrophotometer (HACH, Düsseldorf, Germany). Digestion solution COD-kit (HACH, NANOCOLOR ${ }^{\circledR}$ Düsseldorf, Germany) with a detection range of 1-15,000 g/L was used. 
The concentration of VFAs including acetic, propionic, butyric, isobutyric, valeric and isovaleric acid were analyzed by HPLC (Waters 2695, Waters Corporation, Milford, MA, USA), which was equipped with an ion-exchange column (Aminex HPX-87H Bio-Rad, Hercules, CA, USA) and a Waters 2414 UV detector. The column temperature was set at $60^{\circ} \mathrm{C}$ and $5 \mathrm{mM}$ sulfuric acid was used as eluent with a flow rate of $0.6 \mathrm{~mL} / \mathrm{min}$.

Analysis of D-limonene in the substrate, eluent and solid retentate were conducted using gas chromatography coupled to a mass spectroscopy detector (GC-MS Trace GC Ultra, ThemoScientific, Waltham, MA, USA). The GC-MS was equipped with silica capillary column (ZB-5MS fused-silica with $30 \mathrm{~m} \times 0.25 \mathrm{~mm}$ id $\times 0.25 \mu \mathrm{m}$ film). Helium was used as the carrier gas with a flow rate of $1.2 \mathrm{~mL} / \mathrm{min}$. The temperature of the column was set at $50^{\circ} \mathrm{C}$ for $2 \mathrm{~min}$ and the temperature was increased to $120^{\circ} \mathrm{C}$ with a rate of $4^{\circ} \mathrm{C} / \mathrm{min}$. The injector temperature was set at $250{ }^{\circ} \mathrm{C}$, and the detector temperature was set at $280^{\circ} \mathrm{C}$. Before analysis, the citrus essential oil was extracted from the sample using Soxhlet method with minor modification [21,22]. Ten grams of material was diluted with $200 \mathrm{~mL}$ of heptane. The extraction was run for three hours and the solvent was removed by evaporation to achieve $50 \mathrm{~mL}$ solvent extract. The solvent extract was filtered through a $0.2 \mu \mathrm{L}$ syringe filter before injected to GC-MS. Nonanal was added as an internal standard.

\subsubsection{Analysis of Solid Fraction}

TS (total solid) and VS (volatile solid) of inoculum and substrate were analyzed with the thermogravimetric method, according to the laboratory analytical procedure by Sluiter et al. [23].

\subsection{Calculation}

The methane can be calculated theoretically using the following equation [24]:

$$
\mathrm{C}_{\mathrm{c}} \mathrm{H}_{\mathrm{h}} \mathrm{O}_{\mathrm{o}} \mathrm{N}_{\mathrm{n}} \mathrm{S}_{\mathrm{s}}+\mathrm{yH} \mathrm{H}_{2} \mathrm{O} \rightarrow \mathrm{xCH}_{4}+\mathrm{nNH}_{3}+\mathrm{sH}_{2} \mathrm{~S}+(\mathrm{c}-\mathrm{x}) \mathrm{CO}_{2}
$$

Mol of methane produced $(x)=1 / 8(4 c+h-2 o-3 n-2 s)$

The digestibility of citrus waste calculated as:

$$
\frac{\text { Experimental methane production }}{\text { Theoretical methane production }} \times 100 \%
$$

\section{Results and Discussion}

The first report showing that D-limonene could inhibit methane-forming microorganisms in the rumen was published in 1957 [25]. Since then, several studies have attempted to digest citrus waste in different ways. However, most of the digestion halted at maximum OLR of $2 \mathrm{~g}$ VS/(L·day) [6,26-28]. In this stud, several approaches combining two-stage digestions, filtrations, and an effluent recirculation have been investigated in order to increase the methane production. The first-stage was carried out in a STR whereas the second-stage was carried out in an UASB reactor. In the system with recirculation, the effluent from the second-stage was transferred to the first-stage. In order to evaluate the effect of recirculation, several parameters were measured, including the VS reduction and $\mathrm{pH}$ in the first-stage, as well as the biogas production and composition in the second-stage reactor. Two-stage anaerobic digestion of citrus waste in a system without recirculation was also conducted as control.

\subsection{Effect of Effluent Recirculation on Acidogenesis of Anaerobic Digestion of Citrus Waste In the First-Stage}

The effect of recirculation on $\mathrm{pH}$ during the first-stage of anaerobic digestion of citrus waste is presented in Figure 2. The $\mathrm{pH}$ in the first-stage reactor with recirculation increased gradually from 4.5 to 6.1, whereas the $\mathrm{pH}$ in the reactor without recirculation only increased from 4.4 to 4.7 . This might be explained by high amounts of buffering agents such as bicarbonate and ammonia [29] in the effluent from the second-stage, which could aid in controlling the $\mathrm{pH}$ in the first-stage [29-31]. The effluent 
from the second-stage in reactor with recirculation has a $\mathrm{pH}$ in the range of 7-7.9 (data not shown). This phenomenon was also observed by Aslanzadeh et al. [18] in anaerobic digestion of cotton and starch, in which the $\mathrm{pH}$ of effluent from the second-stage was 8 . The recirculation of the effluent caused the $\mathrm{pH}$ of the first-stage to stabilize over 6.

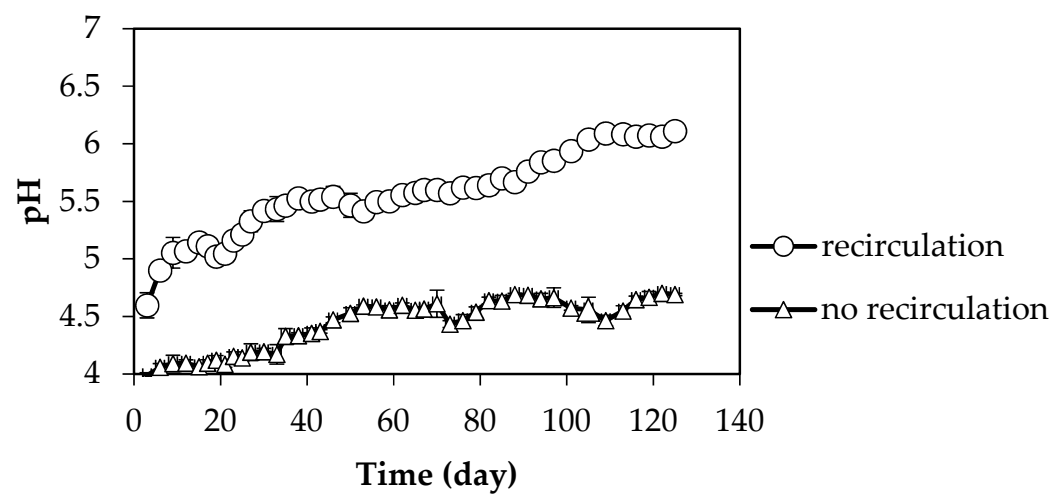

Figure 2. The changes of $\mathrm{pH}$ of the first-stage reactor in the system with and without recirculation.

The higher $\mathrm{pH}$ in the reactor with recirculation leads to a higher production of VFAs (Table 2). Volatile fatty acids (or short chain fatty acids) have a pKa of around 4.8 [32]. VFAs can be toxic to microorganisms, and their toxicity depends on the $\mathrm{pH}$. In the first-stage in the reactor without recirculation, the $\mathrm{pH}$ was lower than the $\mathrm{pKa}$. When the $\mathrm{pH}$ in the reactor is lower than its $\mathrm{pKa}$, the VFAs remain in undissociated form. The undissociated forms of VFAs are hydrophobic compounds. This allows them to pass through cell membranes consisting of a phospholipid bilayer, and to disrupt cell systems [33]. Hence, the production of VFAs is reduced. This would explain why there are higher levels of VFAs in the first-stage with recirculation.

Table 2. VFA composition and sugar content of filtrate from the first-stage reactor with and without recirculation.

\begin{tabular}{ccc}
\hline $\begin{array}{c}\text { The Soluble Content of the } \\
\text { Filtrate }\end{array}$ & $\begin{array}{c}\text { The First-Stage Reactor with } \\
\text { Recirculation }(\mathbf{g} / \mathbf{L})\end{array}$ & $\begin{array}{c}\text { The First-Stage Reactor without } \\
\text { Recirculation } \mathbf{( g / L )}\end{array}$ \\
\hline Acetate & Day 47-125 & Day 0-125 \\
Propionate & $7.9 \pm 0.9$ & $2.5 \pm 0.8$ \\
Isobutyrate & $0.8 \pm 0.2$ & $1.1 \pm 0.6$ \\
Butyrate & $0.1 \pm 0.0$ & $0.3 \pm 0.1$ \\
Isovalerate & $0.1 \pm 0.0$ & $0.8 \pm 0.1$ \\
Valerate & $0.0 \pm 0.0$ & $0.0 \pm 0.0$ \\
Caproate & $0.2 \pm 0.0$ & $0.0 \pm 0.0$ \\
Sugar (glucose and fructose) & $0.3 \pm 0.0$ & $0.0 \pm 0.0$ \\
\end{tabular}

Besides having a negative impact on the first-stage, low $\mathrm{pH}$ also affects methane producing microorganisms in the second-stage, as methanogens exhibit optimum growth at $\mathrm{pH}$ of 6.7-7.5 [24]. The lack of L-muramic acid in the cell membrane structure of methanogens makes them more sensitive to acids. The impact of a low $\mathrm{pH}$ is more pronounced in a one-stage system where acidification and methanogenesis occur in the same reactor. Since a low $\mathrm{pH}$ increases the antimicrobial activity of essential oil [34], the presence of D-limonene in the reactor combined with a low $\mathrm{pH}$ enhances its toxic effect. In order to control pH levels in the first-stage where acidification occurs, a base solution can also be added to the reactor. However, this approach is undesirable due to the economic cost and environmental impact of the production of this chemical. Hence, recirculation offers an advantage as no additional chemical is needed. 
Recirculation not only positively affected the $\mathrm{pH}$ and VFA production, but also improved substrate degradation. This was indicated by a higher and more stable soluble COD value in the filtrate compared to the reactor without recirculation (Figure 3). The higher VS reduction in the recirculation reactor is in accordance with the higher VFA production. VS reduction of the system with recirculation was 32-34\%, while for the system without recirculation it was $15-21 \%$. One possible explanation could be that the reactor with recirculation has an optimum $\mathrm{pH}$ for VFA production. In addition, the performance improvement with recirculation might be related to the shifting of the microbial community towards the acidogenic and acetogenic community as suggested by Giulano et al. [15]. With the approximate values of $33 \%$ and $18 \%$ in the reactors with and without recirculation, respectively, the VS reduction is comparatively low. The reason for this could be that the OLR used in this study was high at $5 \mathrm{~g}$ $\mathrm{VS} /(\mathrm{L} \cdot$ day), as was the loading rate of D-Limonene. Nonetheless, if recirculation is applied to a non-toxic substrate such as starch, the degradability can reach up to $91 \%$ of the theoretical value [18].

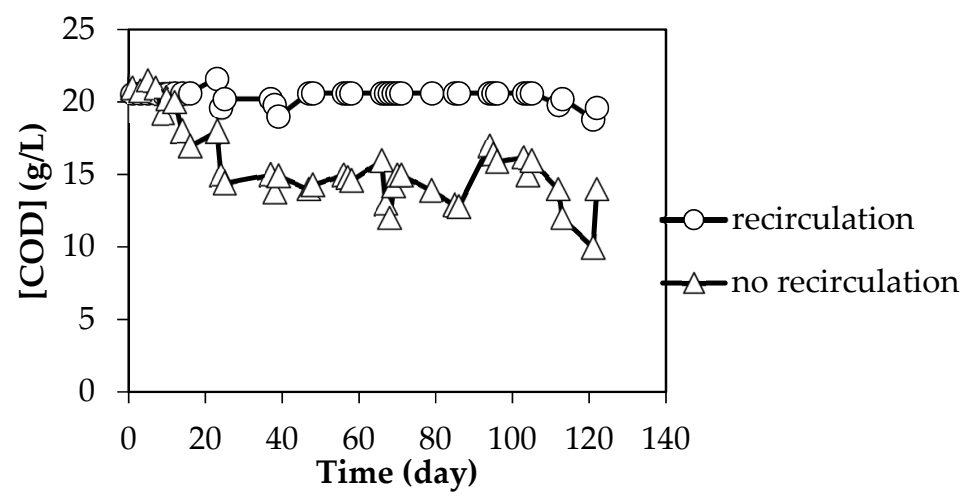

Figure 3. The profile of COD of filtrate from first-stage reactor (STR) with and without recirculation in the system.

\subsection{Effect of Effluent Recirculation on Methane Production of Anaerobic Digestion of Citrus Waste in the Second-Stage}

An up-flow anaerobic sludge blanket (UASB) reactor was used as the second-stage reactor in this study because this type of reactor is considered more effective and shows higher resistance to toxicity than a stirred tank reactor (STR) configuration [27]. The VFA-rich filtrate of effluent from the first-stage was fed into the second-stage to be further converted into methane. The HRT of both the recirculated and non-recirculated system was shortened from 3 to 1.5 days to help the microorganisms adapt.

The $\mathrm{pH}$ of the effluent from the reactors in the second-stage in both systems was stable above 7 , indicating that both reactors were able to consume most of the VFA. This is also shown by the low VFA concentration in the effluent that is correlated to $90 \%$ of VFA consumption in both systems (Table 3). In addition, the higher $\mathrm{pH}$ above 7 also indicates that buffer agents are present in the effluent from the reactors in the second-stage. In line with VFA consumption, the COD was reduced by $90 \%$ in the second-stage reactor for both systems (Table 3). The high COD reduction in the second-stage could be explained by the lower D-limonene content in the filtrate $(0.2 \%)$ compared to the solid phase $(0.8 \%)$. D-Limonene is insoluble in water; hence it tends to be retained in the solid phase rather than in the liquid phase. These results prove the advantage of filtration for D-limonene removal in two-stage digestion.

Biogas composition in both systems with and without recirculation was similar (Table 3). The methane content in both systems was within a similar range as other reports [35-37]. No hydrogen was detected in either system. These results reveal that recirculation did not affect biogas composition. The methane yield from the second-stage is shown in Figure 4. The results showed that methane production was two times higher in the system with recirculation $(160-203 \mathrm{NmL} /(\mathrm{g} \cdot \mathrm{VS} \cdot$ day)) compared to the system without recirculation (66-113 NmL/(g.VS·day)). The higher VFA in the effluent of the first-stage in the system with recirculation might be the reason for the higher methane production. Similarly, Stabnikova et al. [38] reported that $40 \%$ higher methane production was obtained by 
recirculation of effluent from the second-stage into the first-stage in anaerobic digestion of food waste. The authors proposed that recirculation could enhance the acidogenesis process by preventing an excess of acid and providing a faster supply of nutrients to the microorganism. A significant effect of recirculation was observed in two-stage anaerobic digestion of vegetable waste at high OLR (above $2.6 \mathrm{~g} \cdot \mathrm{VS} /(\mathrm{L} \cdot$ day $))[39]$.

Table 3. $\mathrm{pH}$, total VFA, COD reduction of effluent from the second-stage reactor with and without recirculation.

\begin{tabular}{lcc}
\hline \multicolumn{1}{c}{ Parameter } & $\begin{array}{c}\text { The Second-Stage Reactor with } \\
\text { Recirculation } \\
\text { Day 47-125 }\end{array}$ & $\begin{array}{c}\text { The Second-Stage Reactor } \\
\text { without Recirculation } \\
\text { Day 47-125 }\end{array}$ \\
\hline $\mathrm{pH}$ & $7.9-8.2$ & $7.8-8.2$ \\
Total VFA concentration in the & $0.8-0.9$ & $0.4-0.45$ \\
effluent (g/L) & $89-91$ & $90-92$ \\
$\mathrm{COD}$ reduction $(\%)$ & $61-73$ & $60-74$ \\
$\mathrm{CH}_{4}(\%)$ & $28-389$ & $256-40$ \\
$\mathrm{CO}_{2}(\%)$ &
\end{tabular}

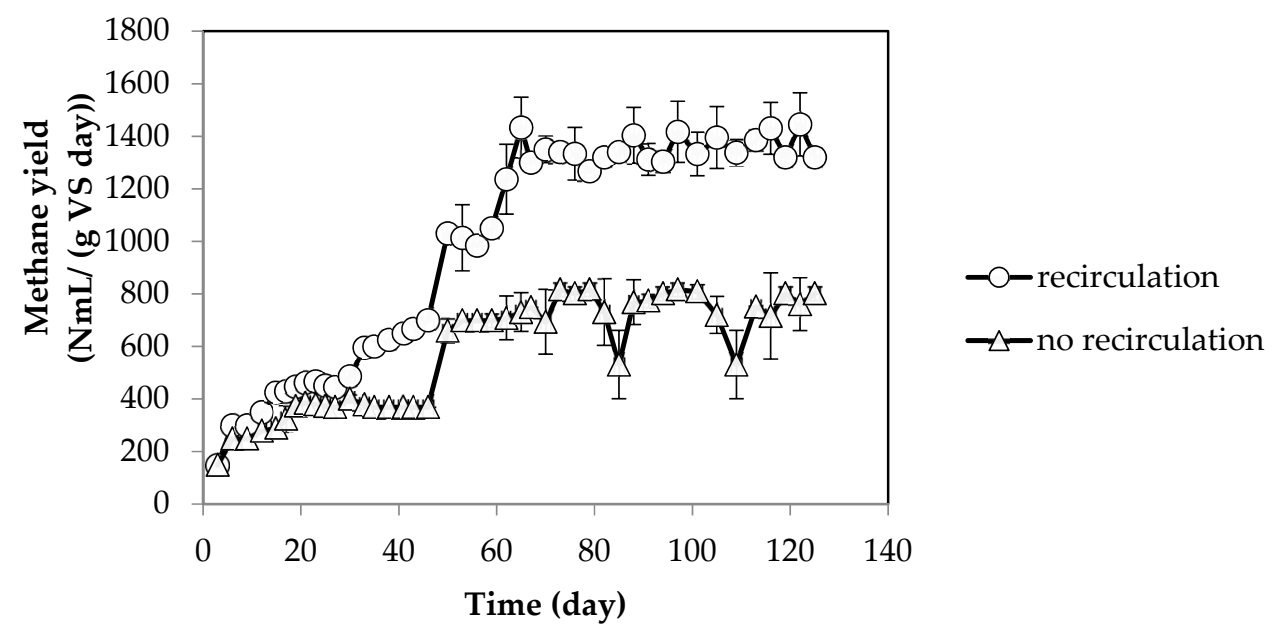

Figure 4. The methane production of second-stage reactor (UASB) with and without recirculation in the system.

Few studies have attempted to find out the mechanism behind the improvement of the anaerobic digestion performance by recirculation. Degueurce et al [40] reported that effluent recirculation from anaerobic digestion of manure produced biotic and abiotic effects. The biotic effect is changing the microbiological community, whereas the abiotic effect is providing nutrients, adjusting $\mathrm{pH}$ and buffering the system. Hence, anaerobic digestion with biotic effluent recirculation produced $50 \%$ more methane compared to anaerobic digestion with abiotic effluent recirculation [40]. Recirculation increased the proportion of phylum Firmicutes that has two-fold cellulolytic capabilities, which caused better cellulose degradation and higher VFA production [41]. Higher VFA concentration promotes the shift of methanogen genera from Methanosarcina spp. to Methanothermobacter spp. which is more tolerant to a high concentration of VFA [41]. Digestate recirculation has been also applied in pilot scale and the results proved that recirculation could stabilize the first-stage process [17].

The digestibility of citrus waste in the system with effluent recirculation was 25-33\%. The OLR used in this study (5 g.VS/L/day) was relatively high compared to other previous works. Forgacs et al. [10] investigated methane production from co-digestion of untreated citrus waste and the organic fraction of municipal solid waste with a ratio of 30:70 at OLR $3 \mathrm{~g} \mathrm{VS} / \mathrm{L} /$ day and the process ceased after 26 days. Flotats et al. [8] also investigated co-digestion of citrus waste (50-80\% $w / w)$ and manure with a maximum OLR of $1 \mathrm{~g}$ VS/L/day. Wikandari et al. [7,42] studied the resilience of membrane bioreactors against D-Limonene in a synthetic medium and in real citrus waste. However, the OLR of the citrus waste was only investigated until an OLR of $3 \mathrm{~g}$ VS/L/day. Reverse membrane 
bioreactors have been of interest for the biorefinery process of inhibitor containing substrates [43]. However, the high price and intensive maintenance requirements limit their application in industry. Hence, recirculation, which plays the role of $\mathrm{pH}$ regulator in the acidification stage, is simpler compared to membrane technology, making it more applicable in industry. The result of the current work reveals that the combination of two-stage digestion, filtration, and effluent recirculation can be successfully applied to anaerobic digestion of citrus waste at high OLRs. However, further studies such as microorganism's community analysis might be performed in order to broaden the knowledge in this study.

\section{Conclusions}

Recirculation has been shown to successfully increase the methane yield of anaerobic digestion of citrus waste in a two-stage process. Furthermore, recirculation system gives higher degradability as shown by VS reduction and VFA content than that of without recirculation system. Having recirculated the second-stage effluent into the first-stage reactor helped to increase the $\mathrm{pH}$ in the first-stage reactor. This leads a better condition for VFA production in the first-stage. In addition, filtration can be used to minimize the amount of D-limonene entering the system in the second-stage. Based on these results, it can be concluded that the combination of recirculation and filtration can be a promising strategy for anaerobic digestion of citrus waste at high OLRs.

Author Contributions: Conceptualization, M.J.T.; Data curation, L.; Formal analysis, L.; Funding acquisition, L. and M.J.T.; Investigation, L.; Methodology, L. and M.J.T.; Project administration, R.M. and M.J.T.; Resources, M.J.T.; Supervision, R.M., M.J.T. and C.N.; Validation, M.J.T.; Writing—original draft, L.; Writing—review \& editing, L., R.W., R.M. and C.N.

Funding: This work was financially supported by the Indonesia Endowment Fund for Education (LPDP) (PRJ-293/LPDP/2015) and the Swedish Research Council.

Acknowledgments: The authors are grateful for the technical help received from Päivi Yltervo during the analyses using GC-MS. The authors would also like to thank Ralf Damaschke for the feedback on the language in this manuscript.

Conflicts of Interest: The authors declare no conflict of interest.

\section{References}

1. Lane, A.G. Removal of peel oil from citrus peel press liquors before anaerobic digestion. Environ. Technol. 1983, 4, 65-72. [CrossRef]

2. Lohrasbi, M.; Pourbafrani, M.; Niklasson, C.; Taherzadeh, M.J. Process design and economic analysis of a citrus waste biorefinery with biofuels and limonene as products. Bioresour. Technol. 2010, 101, 7382-7388. [CrossRef] [PubMed]

3. Food and Agriculture Organization of the United Nations. Available online: http://www.faostat.fao.org (accessed on 1 September 2018).

4. Ángel Siles López, J.; Li, Q.; Thompson, I.P. Biorefinery of waste orange peel. Crit. Rev. Biotechnol. 2010, 30, 63-69. [CrossRef] [PubMed]

5. Moufida, S.; Marzouk, B. Biochemical characterization of blood orange, sweet orange, lemon, bergamot and bitter orange. Phytochemistry 2003, 62, 1283-1289. [CrossRef]

6. Mizuki, E.; Akao, T.; Saruwatari, T. Inhibitory effect of citrus unshu peel on anaerobic digestion. Biol. Wastes 1990, 33, 161-168. [CrossRef]

7. Wikandari, R.; Millati, R.; Cahyanto, M.N.; Taherzadeh, M.J. Biogas production from citrus waste by membrane bioreactor. Membranes 2014, 4, 596-607. [CrossRef]

8. Ruiz, B.; de Benito, A.; Rivera, J.D.; Flotats, X. Assessment of different pre-treatment methods for the removal of limonene in citrus waste and their effect on methane potential and methane production rate. Waste Manag. Res. 2016, 34, 1249-1257. [CrossRef]

9. Mandal, T.; Mandal, N.K. Comparative study of biogas production from different waste materials. Energy Convers. Manag. 1997, 38, 679-683. [CrossRef] 
10. Forgács, G.; Pourbafrani, M.; Niklasson, C.; Taherzadeh, M.J.; Hováth, I.S. Methane production from citrus wastes: Process development and cost estimation. J Chem. Technol. Biotechnol. 2012, 87, 250-255. [CrossRef]

11. Martín, M.A.; Fernández, R.; Serrano, A.; Siles, J.A. Semi-continuous anaerobic co-digestion of orange peel waste and residual glycerol derived from biodiesel manufacturing. Waste Manag. 2013, 33, 1633-1639. [CrossRef]

12. Kim, M.-S.; Cha, J.; Kim, D.-H. Chapter 11-Fermentative biohydrogen production from solid wastes. In Biohydrogen, 1st ed.; Pandey, A., Chang, J.-S., Hallenbecka, P.C., Larroche, C., Eds.; Elsevier: Amsterdam, The Netherlands, 2013; pp. 259-283.

13. Zhu, H.; Parker, W.; Basnar, R.; Proracki, A.; Falletta, P.; Béland, M.; Seto, P. Biohydrogen production by anaerobic co-digestion of municipal food waste and sewage sludges. Int. J. Hydrogen Energy 2008, 33, 3651-3659. [CrossRef]

14. Angelidaki, I.; Sanders, W. Assessment of the anaerobic biodegradability of macropollutants. Rev. Environ. Sci. Bio-Technol. 2004, 3, 117-129. [CrossRef]

15. Giuliano, A.; Zanetti, L.; Micolucci, F.; Cavinato, C. Thermophilic two-phase anaerobic digestion of source-sorted organic fraction of municipal solid waste for bio-hythane production: Effect of recirculation sludge on process stability and microbiology over a long-term pilot-scale experience. Water. Sci. Technol. 2014, 69, 2200-2209. [CrossRef]

16. National Center for Biotechnology Information. Available online: https://pubchem.ncbi.nlm.nih.gov/ compound/-Limonene\#section=Stability-and-Reactivity (accessed on 23 September 2018).

17. Gottardo, M.; Micolucci, F.; Bolzonella, D.; Uellendahl, H.; Pavan, P. Pilot scale fermentation coupled with anaerobic digestion of food waste - effect of dynamic digestate recirculation. Renew. Energy 2017, 114, 455-463. [CrossRef]

18. Aslanzadeh, S.; Rajendran, K.; Jeihanipour, A.; Taherzadeh, M. The effect of effluent recirculation in a semi-continuous two-stage anaerobic digestion system. Energies 2013, 6, 2966-2981. [CrossRef]

19. Millati, R.; Permanasari, E.D.; Sari, K.W.; Cahyanto, M.N.; Niklasson, C.; Taherzadeh, M.J. Anaerobic digestion of citrus waste using two-stage membrane bioreactor. Mater. Sci. Eng. 2018, 316. [CrossRef]

20. Aslanzadeh, S.; Rajendran, K.; Taherzadeh, M.J. A comparative study between single- and two-stage anaerobic digestion processes: Effects of organic loading rate and hydraulic retention time. Int. Biodeterior. Biodegrad. 2014, 95, 181-188. [CrossRef]

21. Kurniawan, T.; Lukitawesa; Hanifah, I.; Wikandari, R.; Millati, R.; Taherzadeh, M.J.; Niklasson, C. Semi-continuous reverse membrane bioreactor in two-stage anaerobic digestion of citrus waste. Materials 2018, 11. [CrossRef]

22. Lukitawesa; Safarudin, A.; Millati, R.; Taherzadeh, M.J.; Niklasson, C. Inhibition of patchouli oil for anaerobic digestion and enhancement in methane production using reverse membrane bioreactors. Renew. Energy 2018, 129, 748-753. [CrossRef]

23. Sluiter, A.; Hames, B.; Ruiz, R.; Scarlata, C.; Sluiter, J.; Templeton, D. Determination of Ash in Biomass. Laboratory Analytical Procedure (LAP); Technical report NREL/TP-510-42622; National Renewable Energy Laboratory: Golden, CO, USA, July 2005.

24. Deublein, D.; Steinhauser, A. Biogas from Waste and Renewable Resources, 2nd ed.; John Wiley and Sons: Weinheim, Germany, 2008; pp. 13-14.

25. Crane, A.; Nelson, W.O.; Brown, R.E. Effects of d-limonene and $\alpha$-d-pinene on in vitro carbohydrate dissimilation and methane formation by rumen bacteria. J. Dairy Sci. 1957, 40, 1317-1323. [CrossRef]

26. Lane, A.G. Anaerobic digestion of orange peel. Food Technol. Aust. 1984, 36, 125-127.

27. Lane, A.G. Anaerobic digestion of citrus peel press liquors. Environ. Technol. Lett. 1983, 4, 349-352. [CrossRef]

28. Castillejos, L.; Calsamiglia, S.; Ferret, A. Effect of essential oil active compounds on rumen microbial fermentation and nutrient flow in in vitro systems. J. Dairy Sci. 2006, 89, 2649-2658. [CrossRef]

29. Cavinato, C.; Bolzonella, D.; Fatone, F.; Cecchi, F.; Pavan, P. Optimization of two-phase thermophilic anaerobic digestion of biowaste for hydrogen and methane production through reject water recirculation. Bioresour. Technol. 2011, 102, 8605-8611. [CrossRef] [PubMed]

30. Micolucci, F.; Gottardo, M.; Bolzonella, D.; Pavan, P. Automatic process control for stable bio-hythane production in two-phase thermophilic anaerobic digestion of food waste. Int. J. Hydrogen Energy 2014, 39, 17563-17572. [CrossRef] 
31. Zamanzadeh, M.; Hagen, L.H.; Svensson, K.; Linjordet, R.; Horn, S.J. Anaerobic digestion of food waste-Effect of recirculation and temperature on performance and microbiology. Water Res. 2016, 96, 246-254. [CrossRef] [PubMed]

32. Kanicky, J.R.; Shah, D.O. Effect of degree, type, and position of unsaturation on the pka of long-chain fatty acids. J. Colloid Interface Sci. 2002, 256, 201-207. [CrossRef] [PubMed]

33. Gerardi, M.H. The Microbiology of Anaerobic Digesters, 1st ed.; John Wiley \& Sons, Inc.: Hoboken, NJ, USA, 2003; pp. 17-40.

34. Burt, S. Essential oils: Their antibacterial properties and potential applications in foods-A review. Int. J. Food Microbiol. 2004, 94, 223-253. [CrossRef] [PubMed]

35. De Mes, T.; Stams, A.; Reith, J.; Zeeman, G. Methane production by anaerobic digestion of wastewater and solid wastes. In Bio-Methane E Bio-Hydrogen: Status and Perspectives of Biological Methane and Hydrogen Production; Dutch Biological Hydrogen Foundation-NOVEM: The Hague, The Netherlands, 2003; pp. 58-102.

36. Michalska, K.; Miazek, K.; Krzystek, L.; Ledakowicz, S. Influence of pretreatment with fenton's reagent on biogas production and methane yield from lignocellulosic biomass. Bioresour. Technol. 2012, 119, 72-78. [CrossRef] [PubMed]

37. Noor, M.; Wandel, A.P.; Yusaf, T. Analysis of recirculation zone and ignition position of non-premixed bluff-body for biogas mild combustion. Int. J. Automot. Mech. Eng. 2013, 8, 1176-1186. [CrossRef]

38. Stabnikova, O.; Liu, X.-Y.; Wang, J.-Y. Anaerobic digestion of food waste in a hybrid anaerobic solid-liquid system with leachate recirculation in an acidogenic reactor. Biochem. Eng. J. 2008, 41, 198-201. [CrossRef]

39. Zuo, Z.; Wu, S.; Zhang, W.; Dong, R. Effects of organic loading rate and effluent recirculation on the performance of two-stage anaerobic digestion of vegetable waste. Bioresour. Technol. 2013, 146, 556-561. [CrossRef] [PubMed]

40. Degueurce, A.; Tomas, N.; Le Roux, S.; Martinez, J.; Peu, P. Biotic and abiotic roles of leachate recirculation in batch mode solid-state anaerobic digestion of cattle manure. Bioresour. Technol. 2016, 200, 388-395. [CrossRef] [PubMed]

41. Lin, L.; Yu, Z.; Li, Y. Sequential batch thermophilic solid-state anaerobic digestion of lignocellulosic biomass via recirculating digestate as inoculum-Part 2: Microbial diversity and succession. Bioresour. Technol. 2017, 241, 1027-1035. [CrossRef] [PubMed]

42. Wikandari, R.; Youngsukkasem, S.; Millati, R.; Taherzadeh, M.J. Performance of semi-continuous membrane bioreactor in biogas production from toxic feedstock containing d-limonene. Bioresour. Technol. 2014, 170, 350-355. [CrossRef] [PubMed]

43. Mahboubi, A.; Ylitervo, P.; Doyen, W.; De Wever, H.; Taherzadeh, M.J. Reverse membrane bioreactor: Introduction to a new technology for biofuel production. Biotechnol. Adv. 2016, 34, 954-975. [CrossRef] [PubMed]

Sample Availability: Samples of the citrus waste are available from the authors.

(C) 2018 by the authors. Licensee MDPI, Basel, Switzerland. This article is an open access article distributed under the terms and conditions of the Creative Commons Attribution (CC BY) license (http:/ / creativecommons.org/licenses/by/4.0/). 